\title{
Cotton cultivars x plant population in Montividiu, Goiás, Brazil
}

\author{
Elio de Jesús Rodríguez de la Torre', Fernando Mendes Lamas ${ }^{2}$ \\ ${ }^{1}$ Instituto Goiano de Agricultura, Montividiu, Goiás, Brasil. E-mail: elio.delatorre@iga-go.com.br \\ ${ }^{2}$ Embrapa Agropecuária Oeste, Dourados, Mato Grosso do Sul, Brasil. E-mail: fernando.lamas@embrapa.br
}

Received: 05/08/2020; Accepted: 17/11/2020.

\begin{abstract}
This study aimed to evaluate the quantitative and qualitative aspects of production in different populations of cotton cultivars. Ten cultivars were evaluated annually in four plant populations. A randomized block design with split plots and three replicates was used. The cultivars were placed in plots, and the plant populations were placed in the subplots. The following characteristics were evaluated: fiber percentage, fiber yield $\left(\mathrm{kg} \mathrm{ha}^{-1}\right)$, fiber length (mm), the micronaire index, the short fiber index $(\%)$, and fiber resistance $\left(\mathrm{gf} \mathrm{tex}^{-1}\right)$. In general, the effect of cultivar was much more important than that of the plant population. These results agree with those obtained by several other authors who have claimed that cotton has a high capacity to adapt to certain population ranges. Thus, considering current seed prices, smaller populations can be used without affecting productivity.
\end{abstract}

Keywords: Gossypium hirsutum, Density, Plant arrangement, Fiber yield.

\section{Cultivares de algodão X população de plantas em Montividiu, Goiás, Brasil}

\section{RESUMO}

Este estudo teve como objetivo avaliar os aspectos quantitativos e qualitativos da produção em diferentes populações de cultivares de algodão. Dez cultivares foram avaliadas anualmente em quatro populações de plantas. O delineamento experimental foi em blocos casualizados com parcelas subdivididas e três repetições. Os cultivares foram colocados em parcelas, e as populações de plantas foram colocadas em subparcelas. Foram avaliadas as seguintes características: porcentagem de fibra, rendimento de fibra (kg ha-1), comprimento da fibra (mm), índice micronaire, índice de fibra curta (\%) e resistência da fibra (gf tex-1). Em geral, o efeito do cultivar foi muito mais importante do que o da população de plantas. Esses resultados concordam com os obtidos por vários outros autores que afirmam que o algodão tem uma alta capacidade de se adaptar a certas faixas populacionais. Assim, considerando os preços atuais das sementes, populações menores podem ser usadas sem afetar a produtividade.

Palavras-chave: Gossypiu hirsutun, Densidade, Arranjo de plantas, Produção de fibra. 


\section{Introduction}

In the herbaceous cotton crop (Gossypium hirsutum L.), plant populations have been studied by several authors. The results obtained vary according to the characteristics of the cultivars or methodologies. Some authors have obtained different populations by changing the spacing between rows, whereas others have changed the number of plants per meter. According to Chiavegato et al. (2010), the productivity of a plant population is the result of the sum of the production of each plant, which is inversely proportional to increases in population size. Cotton has a high capacity to compensate for possible variations in plant populations. In years with an adequate distribution and amount of rainfall during the cycle, it has been found that cotton can be grown in a second crop, with a population of 178,000 plants ha ${ }^{-1}$. However, if low rainfall or water deficits during the reproductive development of cotton have been forecasted, populations of 132,000 plants ha ${ }^{-1}$ can be expected (Ferreira et al., 2015).

Several authors have studied plant populations in cotton crops, often using different methodologies. Cia et al. (1996) evaluated the behavior of cotton cultivated with $1.0 \mathrm{~m}$ spacing between rows and densities of 4,8 , and 16 plants $\mathrm{m}^{-1}$, which is equivalent to 4,8 , and 16 plants $\mathrm{m}^{-2}$, and observed that the highest productivity of fiber was obtained in plants grown in higher densities, which were consequently smaller. Cia et al. (2001) studied plants grown in densities of 5.97 to $13.84 \mathrm{~m}^{-1}$ and did not find significant effects of plant density on fiber production. With regard to the responses of cotton to plant architecture, fiber productivity resulting from variations in plant populations has been found to be highly dependent on the cultivar (Kaggwa-Asiimwe et al., 2013).

Alves et al. (2017) studied plant populations of $13,889,1,857,25,000,41,667$, and 125,000 plants ha ${ }^{-1}$ and found that although the increases in plant populations reduced the stem diameter, plant height, leaf area, number of fruits, and fruit mass per plant, these increases did not influence the number of bolls $\mathrm{m}^{-2}$. These results are similar to those obtained by Ren et al. (2013). Overall, the highest yields of cottonseed and fiber were obtained in populations of 71,471 and 72,964 plants $\mathrm{ha}^{-1}$. Stephenson et al. (2011) found that the highest fiber yield was obtained when the plant population reached approximately 11.45 plants $\mathrm{m}^{-2}$. Reddy et al. (2009) set the spacing between rows to $0.38 \mathrm{~m}$ and varied the plant population per unit area by using irrigated or nonirrigated conditions and found that under both irrigation conditions, fiber productivity decreased when the plant population increased.

Considering the quantitative and qualitative aspects of the production of the cultivars available and the harvesting machines in use, Lamas and Ferreira (2013) performed a thorough review and found that the best plant arrangement corresponded to a spacing between rows of $0.76 \mathrm{~m}$ to $0.90 \mathrm{~m}$ with 10 to 12 plants $\mathrm{m}^{-2}$. Moreover, they suggested that the lower limit of number of plants per unit area should be adopted for taller cultivars and the upper limit should be adopted for smaller cultivars.

This study aimed to evaluate the behavior of modern cultivars in different plant populations. The hypothesis of the study was that the best plant population, in terms of yield and the technological characteristics of fiber, would vary depending on the cultivar.

\section{Material and Methods}

The experiments were conducted at the IGA experimental field "Rancho Velho" farm (17²7 '30" S, $\left.51^{\circ} 08^{\prime} 11^{\prime \prime} \mathrm{W}\right)$, located in the municipality of Montividiu, Goiás, Brazil, at an altitude of $895 \mathrm{~m}$. The soil in the experimental area is a dystrophic Red Latosol (LVd) according to the classification of Santos et al. (2018). Chemical-physical analyses of the soil in the experimental area were performed following the methodology proposed by Teixeira et al. (2017). Table 1 presents the results of the analysis of soil samples collected before the experiment was installed. The indepth correction of the soil considered the indications and recommendations of Sousa and Lobato (2004).

Figures 1 and 2 show the distribution of rainfall per decade from December 2017 to June 2018 and from October 2018 to June 2019 in the IGA experimental field in Montividiu, GO.

Sowing was performed on millet straw under adequate soil moisture conditions on December 28, 2017 and December 29, 2018. Ten cultivars and four plant populations were evaluated during these two years and are shown in Table 2.

The experimental plots were composed of six, 30-m rows. The experimental design was composed of randomized blocks with split plots. The cultivars were placed in the plots, and the populations were placed in subplots with three replicates.

Fertilization was performed with $200 \mathrm{~kg} / \mathrm{ha}$ of MAP (9-49-00) in the planting furrow; 150 and $200 \mathrm{~kg} / \mathrm{ha}$ of urea at 15 and 35 days after emergence (DAE), respectively; $150 \mathrm{~kg} / \mathrm{ha}$ of sulfate ammonium at $48 \mathrm{DAE}$; and $250 \mathrm{~kg} / \mathrm{ha}$ of $\mathrm{KCl}$ after planting. Weed management was conducted with non-selective herbicides before sowing cotton with glyphosate. Glyphosate and glufosinate were used during the experiment with the respective cultivars.

The control of pests and diseases through the ondemand spraying of insecticides and fungicides was performed according to the results of insect and pathogen monitoring. The main pests observed were boll weevils 
[Anthonomus grandis (Coleoptera: Curculionidae)], aphids [Aphis gossypii (Hemiptera: Aphidae)], red spider mites [Tetranychus urticae (Acarina: Tetranychiadae)], and caterpillars (Spodoptera sp.), which were controlled with specific insecticides and acaricides. The products were chosen according to the mechanism of action. The main diseases observed were white mold [Sclerotinia sclerotiorum (Lib.)] and areolate mildew [Ramularia areola (Atk.)], which were controlled with specific fungicides. The management of plant growth was conducted with growth regulator applied according to the vigor of the plants, climate conditions, and soil fertility.

A total of $0.5 \mathrm{~L} / \mathrm{ha}$ of the commercial product containing $120 \mathrm{~g} / \mathrm{L}$ tidiazuron $+60 \mathrm{~g} / \mathrm{L}$ diuron was applied to defoliate the plants for harvest when the plants had $70 \%$ bolls, and $1.5 \mathrm{~L} / \mathrm{ha}$ of a product containing etefom $480 \mathrm{~g} / \mathrm{L}+$ cyclanilide $60 \mathrm{~g} / \mathrm{L}$ was applied after 10 days to promote fruit opening.

The data obtained were evaluated with an analysis of variance (ANOVA). When a significant difference was present, the means of the qualitative treatments (cultivars) were compared with a post-hoc Tukey test at the 5\% significance level, and the means of the quantitative treatments (populations) were subjected to polynomial regression analysis. When the cultivar and population interaction was significant, the interaction was broken down and the behavior of each cultivar was analyzed according to the plant population.

Table 1. Chemical characteristics and granulometric composition of the soil before the experiment was installed. IGA crop season 2017-18. Montividiu, Goiás, Brazil.

\begin{tabular}{|c|c|c|c|c|c|c|c|c|c|c|}
\hline \multirow[t]{2}{*}{ Prof $(\mathrm{cm})$} & \multicolumn{2}{|c|}{$\mathrm{pH}$} & P-Res & K & $\mathrm{Zn}$ & $\mathrm{Cu}$ & $\mathrm{Fe}$ & $\mathrm{Mn}$ & $\mathrm{s}$ & B \\
\hline & $\mathrm{H}_{2} \mathrm{O}$ & $\mathrm{CaCl}_{2}$ & \multicolumn{2}{|c|}{ cmolc.dm ${ }^{-3}$} & \multicolumn{6}{|c|}{ 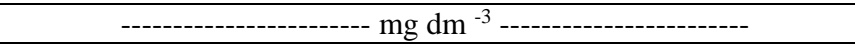 } \\
\hline $0-10$ & 6.2 & 5.2 & 32.5 & 70.0 & 0.9 & & 20.0 & 1.99 & & 0.33 \\
\hline $0-20$ & 6.0 & 5.0 & 32.5 & 60.0 & 1.0 & 0.5 & 29.0 & 1.91 & & 0.32 \\
\hline $20-40$ & 5.8 & 4.8 & 12.0 & 46.0 & & & & & 60.0 & \\
\hline \multirow[t]{2}{*}{ Prof $(\mathrm{cm})$} & $\mathrm{Ca}$ & $\mathrm{Mg}$ & $\mathrm{Al}$ & $\mathrm{H}+\mathrm{Al}$ & CTC & $\mathrm{V}$ & Sand & Silt & Clay & $\mathrm{MO}$ \\
\hline & \multicolumn{5}{|c|}{ 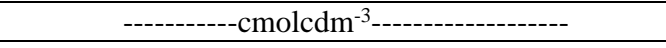 } & \multicolumn{5}{|c|}{ |---------------------\% \%----------------------- } \\
\hline $0-10$ & 4.2 & 1.3 & 0.0 & 3.5 & 9.1 & 61.7 & & & & \\
\hline $0-20$ & 2.8 & 0.8 & 0.0 & 5.4 & 9.2 & 41.1 & 28.0 & 3.0 & 69.0 & 3.7 \\
\hline $20-40$ & 1.7 & 0.5 & 0.1 & 4.7 & 7.0 & 33.0 & & & & \\
\hline
\end{tabular}

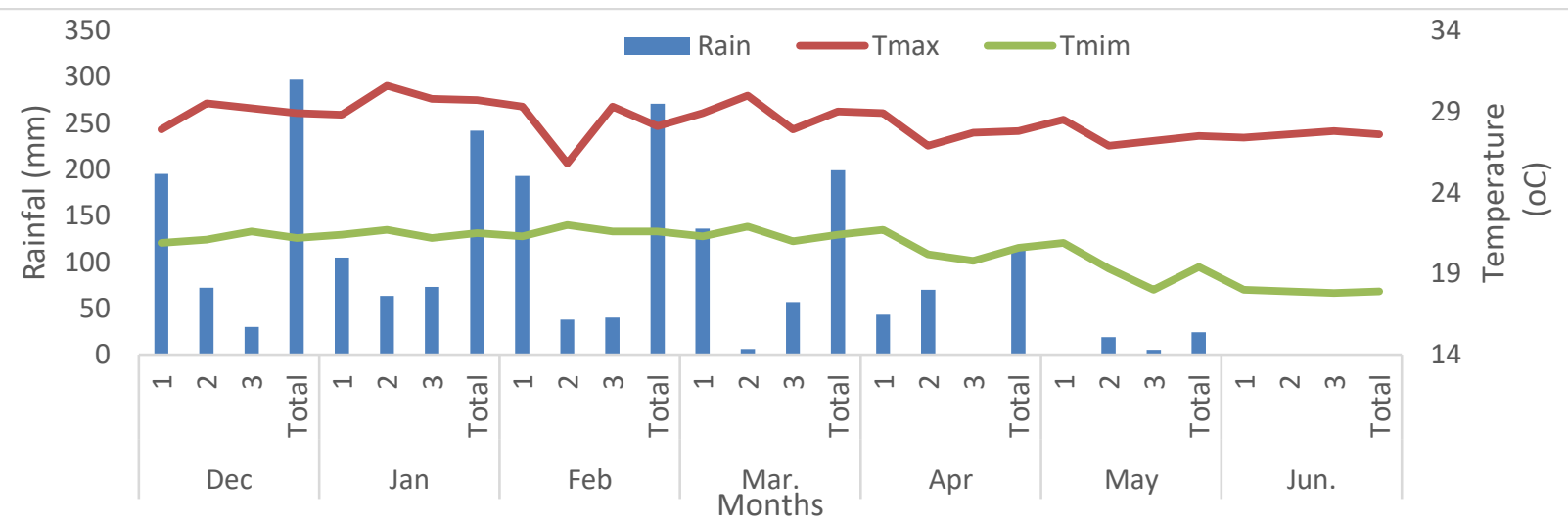

Figure 1. Rainfall $(\mathrm{mm})$ and max and min temperature $\left({ }^{\circ} \mathrm{C}\right)$ in the IGA experimental field in Montividiu, Goiás, Brazil, from September 2017 to June 2018. Montividiu, GO, 2020.

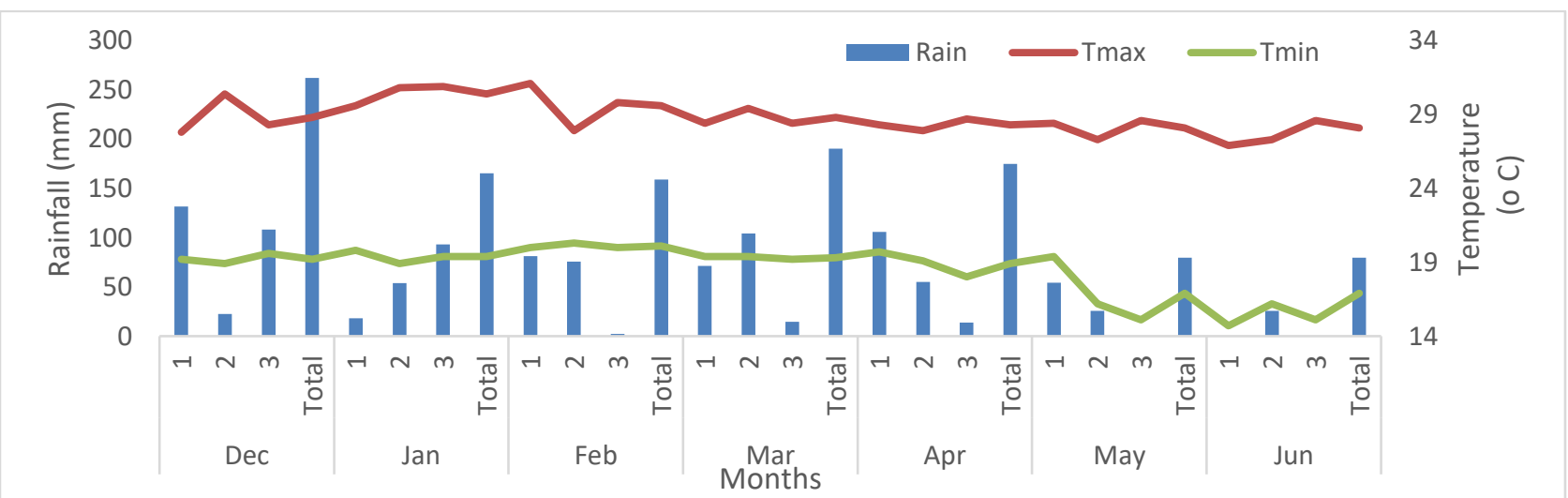

Figure 2. Rainfall (mm) max and min temperature $\left({ }^{\circ} \mathrm{C}\right)$ in the IGA experimental field in Montividiu, Goiás, Brazil, from September 2018 to June 2019. Montividiu, GO, 2020. 
Table 2. Cultivars and plant populations evaluated in 2017/2018 and 2018/2019 in Montividiu, Goiás, Brazil.

\begin{tabular}{cccc}
\hline \multicolumn{2}{c}{ Cultivars } & \multicolumn{2}{c}{ Populations (plants m ${ }^{-2}$ ) } \\
\hline 2017/2018 & 2018/2019 & $2017 / 2018$ & $4.4 ; 6.6 ; 8.9$, and 11.1 \\
TMG 44 B2RF & TMG 44 B2RF & $6.6 ; 9.213 .15$, and 17.10 & \\
DP 1536 B2RF & DP 1746 B2RF & & \\
DP 1746 B2RF & IMA 5801 B2RF & & \\
IMA 5801 B2RF & FM 954 GLT & \\
FM 954 GLT & FM 906 GLT & \\
FM 906 GLT & FM 983 GLT & \\
FM 983 GLT & FM 985 GLTP & \\
FM 985 GLTP & IMA 6801 B2RF & & \\
BBX1506 & DP 1637 B2RF & & \\
\hline
\end{tabular}

\section{Results and Discussion}

When analyzing the fiber percentage (PFIBRA), fiber yield (PRODU), micronaire index (MIC), short fiber index (SFI), and fiber resistance (STR), the analysis of variance showed significant effects on the cultivar. However, when fiber productivity (PRODU), length (LEN), and the micronaire index (MIC) were evaluated at $1 \%$ probability by a Fisher F-test, statistical analyses indicated significant results for population. The interaction between cultivar and plant population was also significant for fiber yield (RENDF), LEN, and PRODU (Table 3).

In 2018/2019, the effect of cultivar was significant for PRODU, LEN, MIC, SFI, and STR. The effect of the plant population was only not significant for LEN and STR. The same was true for the interaction between the cultivar and plant population ( $\mathrm{P}>0.05$; Table 4$)$.

In the 2017/2018 crop season, the effect of the plant population on the PFIBRA values varied significantly between cultivars. The PFIBRA values for the TMG 44 B2RF, DP 1746 B2RF, and IMA 5801 B2RF cultivars decreased linearly as a result of increases in the size of plant population. The data for cultivar DP 1536 B2RF was fitted to a cubic model (Figure 3). The effect of the plant population was not significantly influenced by the plant populations of the other cultivars analyzed (Figure 3 ). In the 2018/2019 crop season, the effect of the size of the plant population on PFIBRA was significant only for some of the cultivars analyzed. The PFIBRA value decreased linearly as a result of the increase in the plant population in the IMA 6801 B2RF and FM 906 GLT cultivars. For the FM 954 GLT and FM 944 GL cultivars, the data was fitted to a quadratic model, with a maximum and minimum estimated at 7.61 plants $\mathrm{m}^{-2}$ and 8.4 plants $\mathrm{m}^{-2}$, respectively (Figure 4). The PFIBRA is an agronomic characteristic that varies between cultivars (Araújo et al., 2013). Although it is a very prominent characteristic of a cultivar, the PFIBRA is highly influenced by the environment, which explains the difference in the responses of the cultivars between years (Meredith Junior et al., 2012). The climatic conditions during the experiment indicated that the average minimum temperature was lower during a longer period (especially at the end of the cycle) in 2018/2019 compared to that of $2017 / 2018$. This may have influenced the PFIBRA values, particularly in the fruits located in the upper thirds of the plants.

The effect of the plant population on the fiber yield in 2017/2018 was significant for the TMG 47 B2RF, DP 1536 B2RF, DP 1746 B2RF, and FM 985 GLTP cultivars, with a quadratic model for the first two cultivars and linear adjustments for the others (Figure 5). For cultivars with a quadratic adjustment according to the plant population, minimum values of 13.73 and 12.58 plants $\mathrm{m}^{-2}$ were estimated for the TMG $47 \mathrm{~B} 2 \mathrm{RF}$ and DP 1536 B2RF cultivars, respectively.

Table 3. Summary of the analysis of variance of the experiment conducted in 2017/2018 in Montividiu, Goiás, Brazil. Abbreviations: fiber percentage (PFIBRA), fiber yield (PRODU), length (LEN), micronaire index (MIC), short fiber index (SFI), and fiber resistance (STR).

\begin{tabular}{ccccccc}
\hline FV & \multicolumn{5}{c}{ Medium Square } \\
\cline { 2 - 7 } & PFIBRA & PRODU & LEN & MIC & SFI & STR \\
\hline Block & 2.93 & 8432.31 & 0.13 & 0.002 & 0.77 & 0.05 \\
Cultivar (C) & $153.36^{* *}$ & $705161.65^{* *}$ & $4.77^{* *}$ & $0.95^{* *}$ & $17.94^{* *}$ & $16.27^{* *}$ \\
\hline Error (a) & 0.41 & 37464.86 & 0.31 & 0.03 & 0.99 & 1.37 \\
\hline Population (P) & $1.03^{\mathrm{ns}}$ & $87847.36^{*}$ & $1.28^{*}$ & $0.12^{*}$ & $1.38^{\mathrm{ns}}$ & $1.34^{\mathrm{ns}}$ \\
C*P & $1.09^{*}$ & $81928.77^{* *}$ & $0.30^{\mathrm{ns}}$ & $0.06^{*}$ & $0.57^{\mathrm{ns}}$ & $1.49^{\mathrm{ns}}$ \\
\hline Error (b) & 0.57 & 28573.47 & 0.34 & 0.03 & 0.79 & 1.47 \\
\hline CVa (a) & 1.47 & 7.93 & 1.88 & 4.85 & 9.17 & 4.05 \\
CVb (b) & 1.73 & 6.92 & 1.96 & 4.74 & 8.19 & 4.20 \\
\hline
\end{tabular}

** Significant at 1\%; * significant at 5\%; NS, not significant at 5\% probability with a Fisher F-test. 
Table 4. Summary of the analysis of variance of the experiment conducted in 2018/2019 in Montividiu, Goiás, Brazil. Abbreviations: fiber percentage (PFIBRA), fiber yield (PRODU), length (LEN), micronaire index (MIC), short fiber index (SFI), and fiber resistance (STR).

\begin{tabular}{|c|c|c|c|c|c|c|}
\hline \multirow[t]{2}{*}{ FV } & \multicolumn{6}{|c|}{ Medium Square } \\
\hline & PFIBRA & PRODU & LEN & MIC & SFI & STR \\
\hline Block & 124.97 & 209070.54 & 0.18 & 0.11 & 0.60 & 0.65 \\
\hline Cultivar (C) & $41.53^{\mathrm{ns}}$ & $1369325.06 * *$ & $6.72 * *$ & $0.79 * *$ & $20.57 * *$ & $6.87 * *$ \\
\hline Error (a) & 405.53 & 32023.83 & 0.33 & 0.03 & 0.62 & 1.04 \\
\hline Population (P) & $198.18 * *$ & $186122.12 * *$ & $1.14^{*}$ & $0.08^{*}$ & $0.82^{\mathrm{ns}}$ & $7.14 * *$ \\
\hline $\mathrm{C} * \mathrm{P}$ & $469.08 *$ & $89702.24 * *$ & $0.44^{\mathrm{ns}}$ & $0.08 * *$ & $1.33^{*}$ & $1.82^{\mathrm{ns}}$ \\
\hline Error (b) & 609.24 & 25816.59 & 0.32 & 0.02 & 0.79 & 0.67 \\
\hline $\mathrm{CVa}(\mathrm{a})$ & 10.15 & 7.46 & 1.92 & 5.04 & 9.23 & 348 \\
\hline $\mathrm{CVb}(\mathrm{b})$ & 6.82 & 6.69 & 1.90 & 3.81 & 10.37 & 279 \\
\hline
\end{tabular}

** Significant at $1 \%$; significant at 5\%; NS, not significant at 5\% probability with a Fisher F-test.

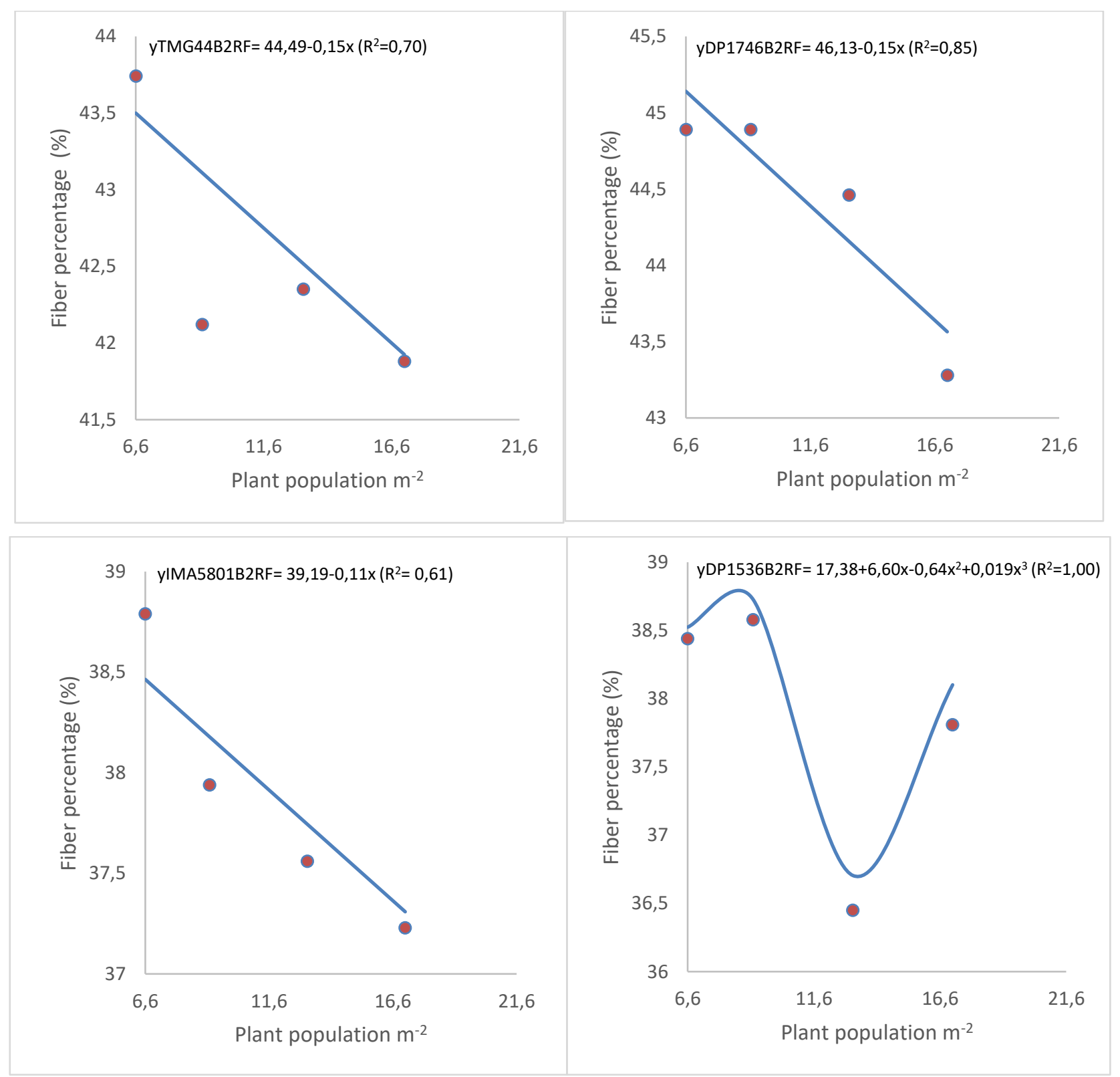

Figure 3. Regression curves for the fiber percentage (PFIBRA) as a function of plant population in the 2017/2018 crop season. Montividiu, Goiás, Brazil. 2020. 

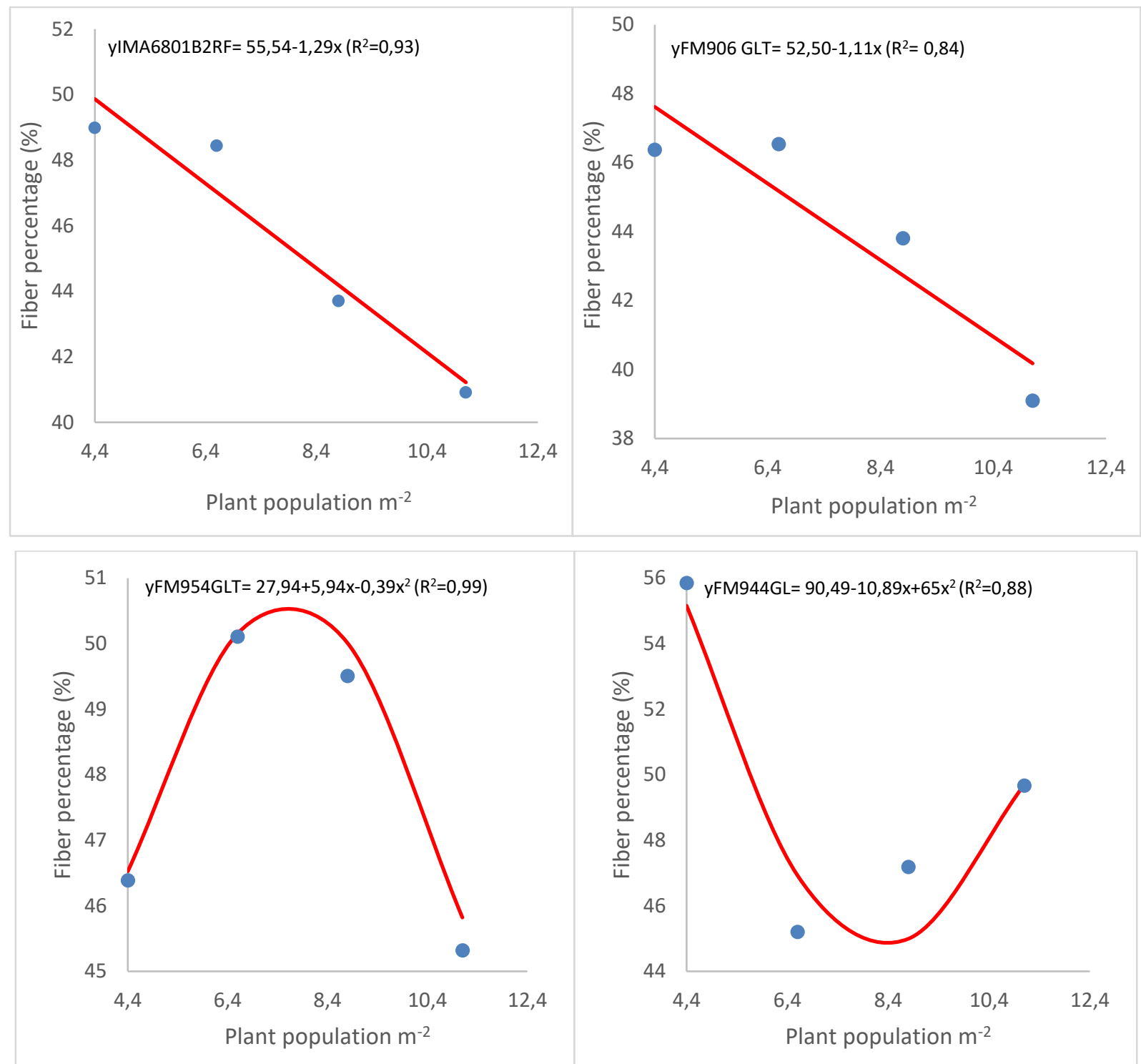

Figure 4. Regression curve for percentage of fiber (PFIBRA) as a function of plant population in the 2018/2019 crop season. Montividiu, Goiás, Brazil. 2020.

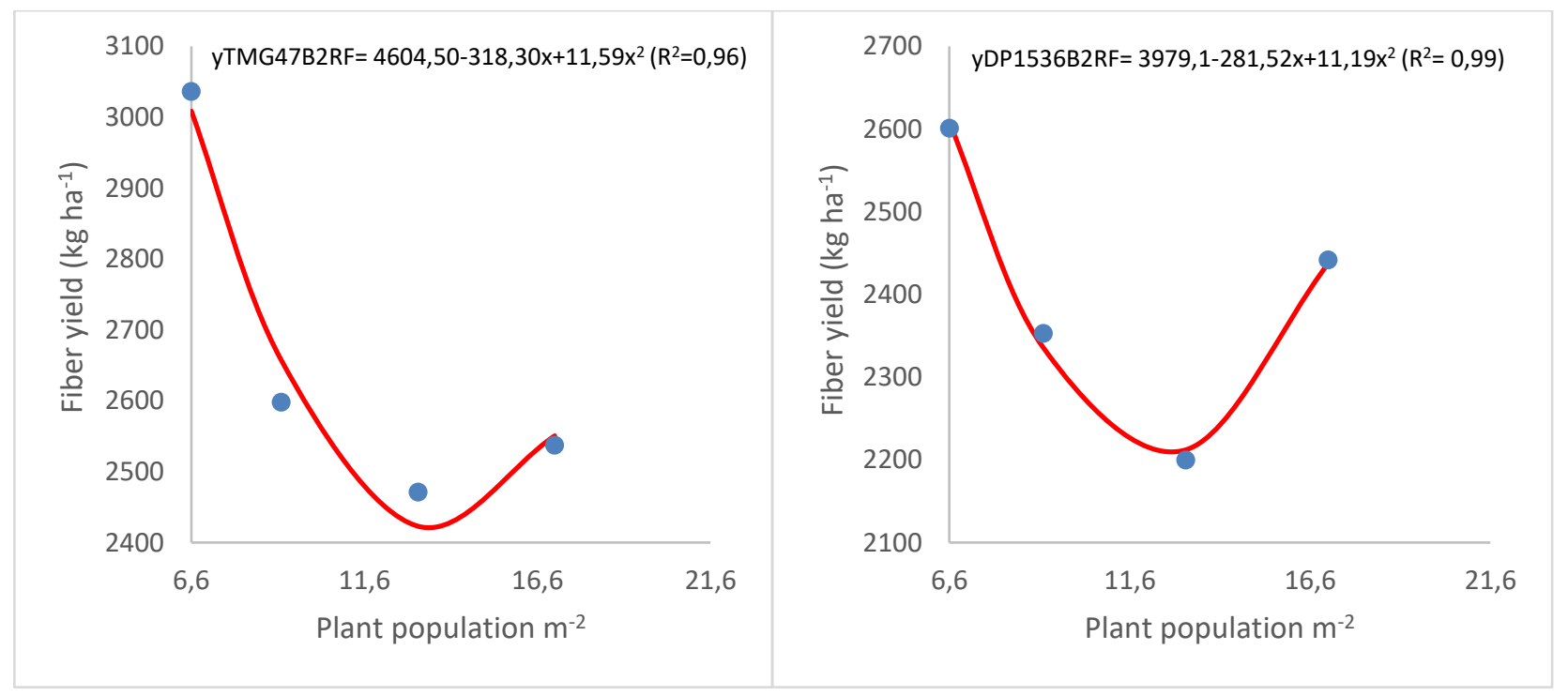



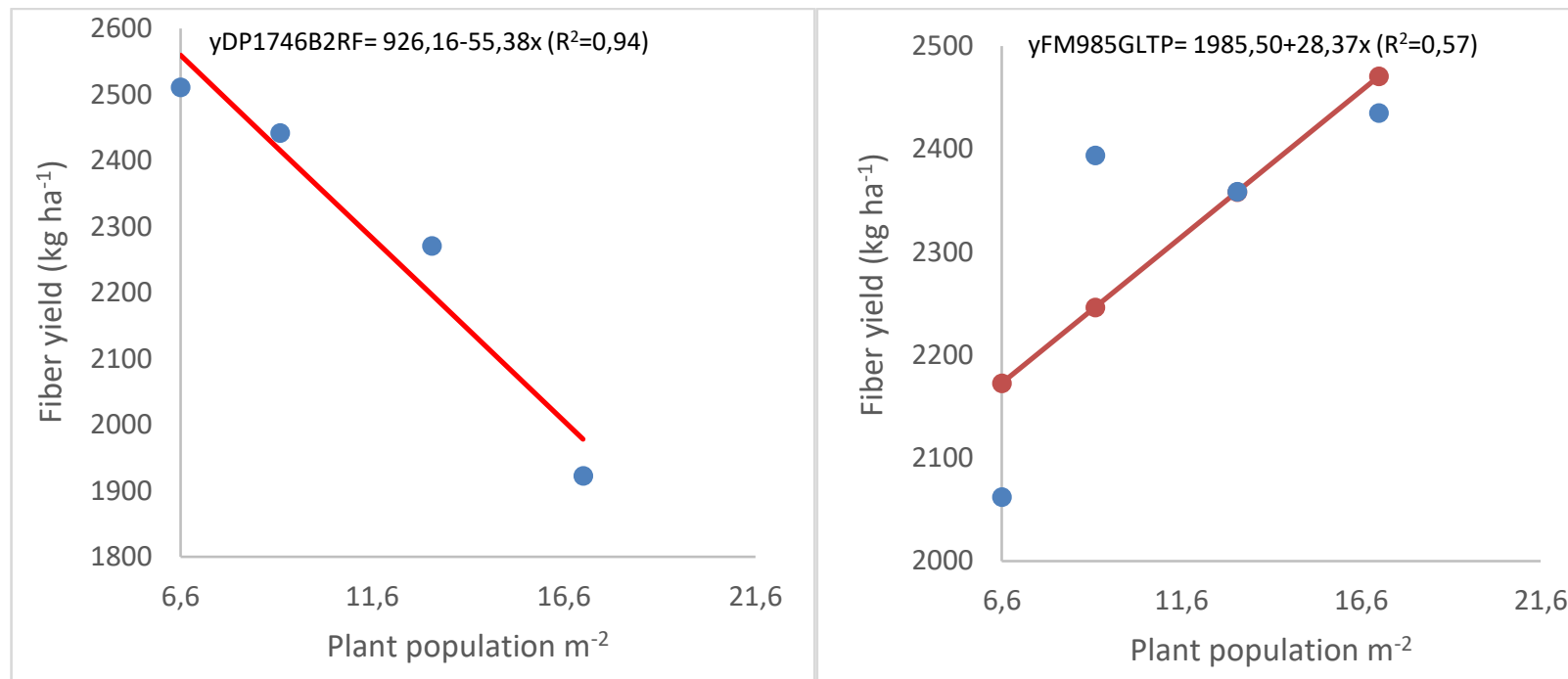

Figure 5. Regression curves for fiber yield $\left(\mathrm{kg} \mathrm{ha}^{-1}\right)$ for cultivars, depending on the plant population, in the 2017/2018 crop season. Montividiu, Goiás, Brazil. 2020.

In 2018/2019, the effect of the plant population on fiber yield was not significant $(\mathrm{P}>0.05)$ for the IMA 5801 B2RF, DP 1637 B2RF, FM 906 GLT, and FM 954 GLT cultivars (Figure 6). Fiber yieldy $\left(\mathrm{kg} \mathrm{ha}^{-1}\right)$ decreased linearly as a result of the increase in the plant population in the IMA 5801 B2RF and FM 954 GLT cultivars. For the DP 1637 B2RF cultivar, PRODU varied quadratically with the plant population, with a minimum estimated at 9.64 plants $\mathrm{m}^{-2}$ (Figure 6).

Ferrari et al. (2008) observed that the number of reproductive branches, bolls per plant, and seed cotton productivity decreased as the plant population increased. Silva et al. (2012) studied the effects of different row spacing and plant densities on fiber productivity and found that only spacing between rows had a significant effect. Working with cultivars in different densities, Ferreira et al. (2015) found that the interaction between cultivar and density was not significant. Moreover, according to these authors, the availability of water in the soil markedly influenced the responses of cotton plants to plant density. Under conditions of high plant density, the reduced availability of light inside the canopy resulted in an increase in the rate of abscission of the reproductive structures, the slow development of structures that were retained, and negative impacts on fiber development, which generally resulted in low MIC values (Silvertooth et al., 1999). Although increases in plant density have been consistently associated with increases in the leaf area index (LAI) and light capture, the effects of plant density on production have been inconsistent (Heitholt and Sassenrath-Cole, 2010).

The variable increases in plant density according to the plant population are due to the ability of the cotton plant to adapt its anatomical structure and physiological functions to accommodate changes in plant density. In a comprehensive review of the effects of plant populations on cotton fiber yields, Adams et al. (2019) concluded that populations with densities below 35,000 and above 81,000 plants $h^{-1}$ showed reduced fiber productivity. Kaggwa-Asiimwe et al. (2013) studied the effects of various plant populations on fiber architecture and yield using two cultivars and concluded that the effects were highly dependent on the cultivar under study. These results are similar to those obtained by Guzmann et al. (2019). However, Kaggwa-Asiimwe et al. (2013) stated that in populations with over 100,000 plants ha ${ }^{-1}$, fiber yields were found to reduce. Alves et al. (2017) studied populations with densities between 25,000 and 125,000 plants $\mathrm{ha}^{-1}$ and found that a reduction in productivity was present with densities greater than 70,000 plants $\mathrm{ha}^{-1}$. In the present study, when significant, the effect of the plant population on fiber yield was positive with densities up to 100,000 plants ha $^{-1}$.

Considering that seed costs comprise a notable portion $(9.63 \%)$ of the expenses associated with a crop (IMEA, 2020) and that the yields of the studied cultivars were not very responsive to increases in plant populations, populations greater than 100,000 plants ha $^{-1}$ should not be used for the production of fiber per unit area. In this study, for several of the cultivars, the effect of the plant population on fiber yield was not significant. In the first year, the population ranged from 66,000 to 170,000 plants $\mathrm{ha}^{-1}$ and in the second year, population ranged from 44,000 to 110,000 plants ha ${ }^{-1}$. According to Chiavegato et al. (2014), the degree of uniformity of the plants in the sowing line is equally or more important than the number of plants.

In 2017/2018 and 2018/2019, the effect of the plant population on the MIC values varied depending on the cultivar. However, for the IMA 5801 B2RF, TMG 44 
B2RF, and FM 954 GLT cultivars, no significant effects were observed when the plant population increased over the two years of study. According to Lima and Bélot (2020), the fiber in this study may be classified as fine to regular (i.e., MIC values greater than 3 and less than 4.9 were observed; Figures 7 and 8).

In the year 2017/2018, the LEN (mm), the SFI (\%), and the STR (gf $\mathrm{Tex}^{-1}$ ) values varied significantly between the cultivars evaluated. The effect of the plant population on LEN was significant, with the data fitted to a linear model. A reduction in LEN was observed as a result of the increase in the plant population (Table 5). In 2018/2019, LEN and STR varied between cultivars, and the interaction between cultivar and plant population was significant for SFI, with the effect being cubic for the FM 983 GLT cultivar and linear for the FM 985 GLTP cultivar. The LEN decreased linearly as the plant population increased (Table 6).

The values obtained for STR varied significantly between the cultivars over the two years. However, the effect of the number of plants was not significant for this characteristic that is intrinsic to the cultivars (Tables 5 and 6). The results obtained in the present study agree with those of Meredith Junior et al. (2012) who evaluated the effect of genotype $(\mathrm{G})$, environment $(\mathrm{E})$, and the $\mathrm{G} x$ A interaction and concluded that STR is primarily influenced by G. In other words, STR is a characteristic that is highly influenced by the cultivar and hardly influenced by the environment. According to Alves et al. (2017), fiber strength is a characteristic that is not influenced by the plant population. According to Lima and Bélot (2020), fiber was found to vary from medium to resistant values. According to these authors, the LEN and SFI of most cultivars are medium and low to regular, respectively.

Considering the different cultivars and populations in the present study, plant populations between 7.8 and 13.73 plants $\mathrm{m}^{-2}$ provided the highest fiber yields, thus demonstrating the ability of cotton plants to adapt without quantitative losses. The population sizes recommended by the breeders of the evaluated cultivars varied between 7.7 and 13.15 plants $\mathrm{m}^{-2}$. Some breeders recommend larger cotton populations in the second harvest.

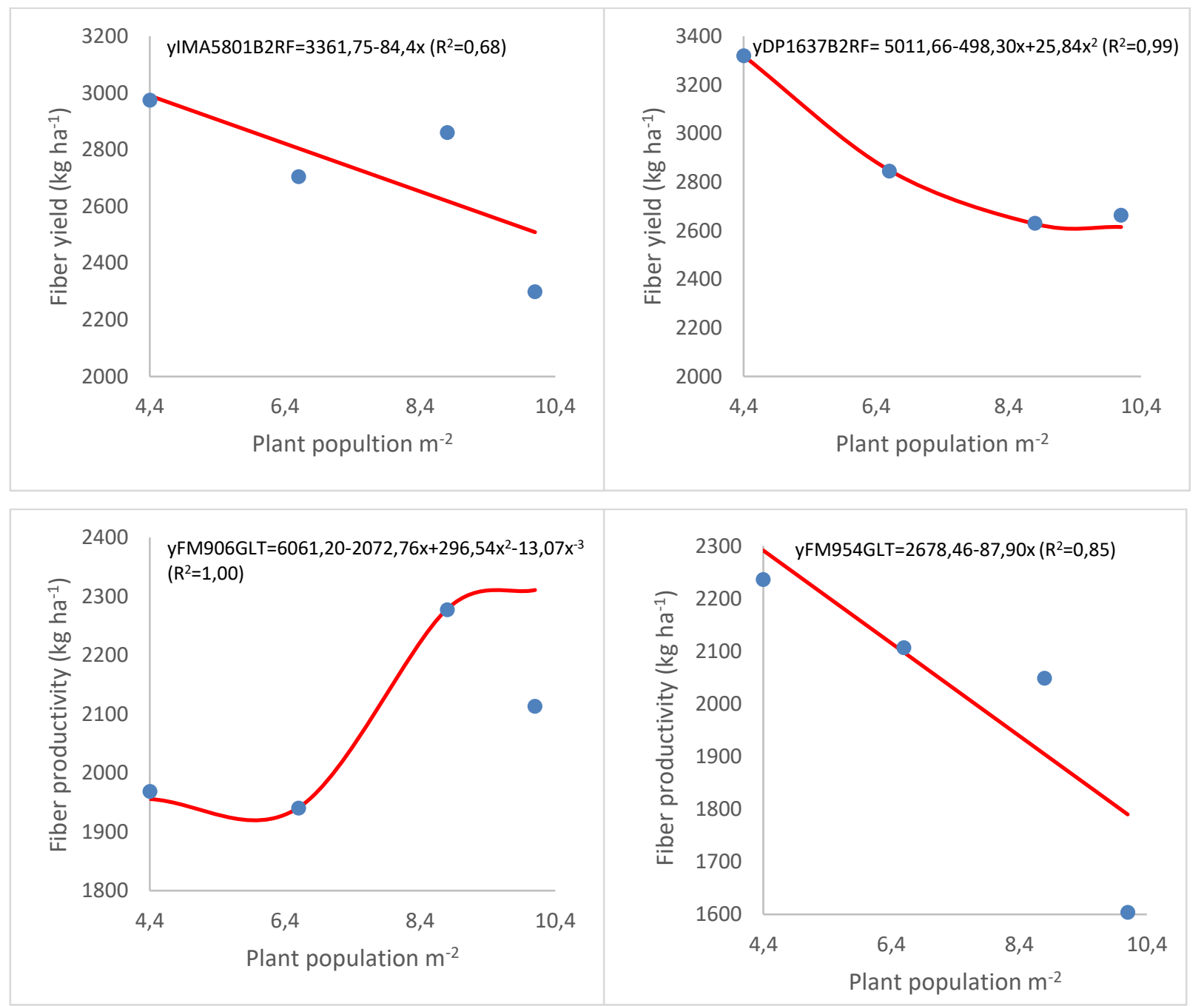

Figure 6. Regression curves for fiber yield (PRODU, $\mathrm{kg} \mathrm{ha}^{-1}$ ) depending on the plant population in the 2018/2019 crop season. Montividiu, Goiás, Brazil. 2020. 

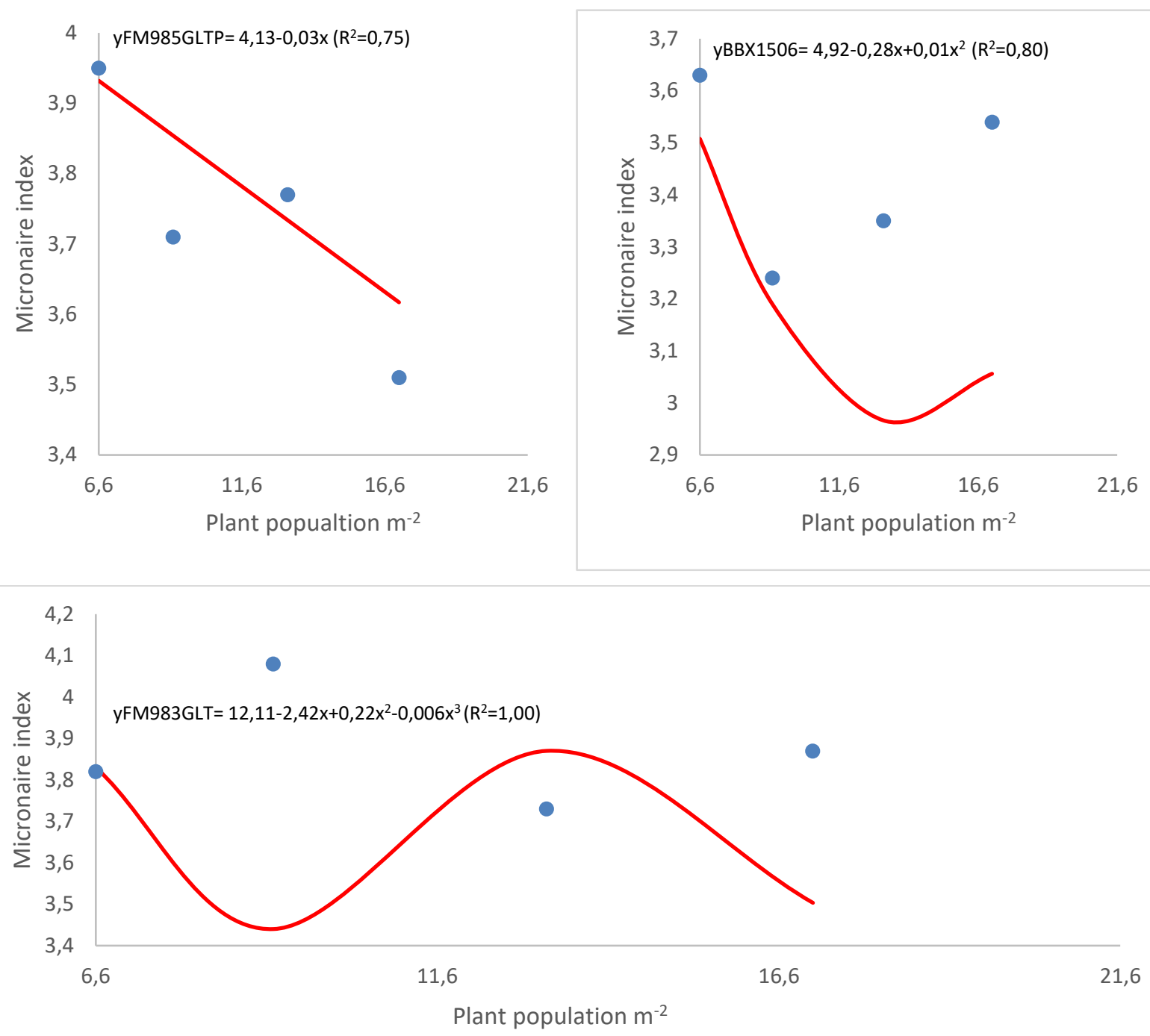

Figure 7. Micronaire index (MIC) regression curves as a function of the plant population in the 2017/2018 crop season. Montividiu, Goiás, Brazil. 2020.

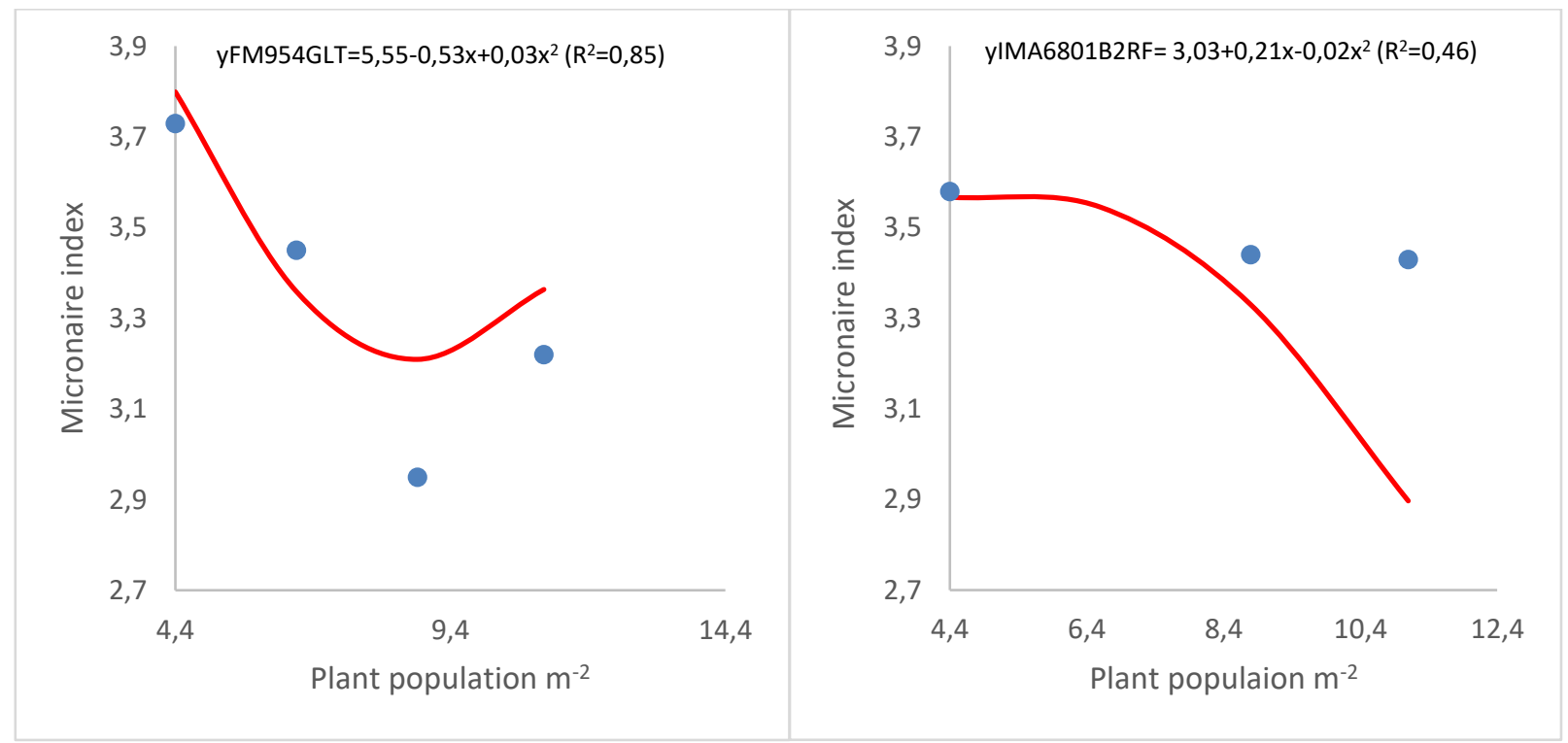

Figure 8. Regression curves for micronaire index as a function of plant population in the 2018/2019 crop season. Montividiu, Goiás, Brazil. 2020. 
Table 5. Fiber length (LEN, mm), short fiber index (SFI, \%), and fiber strength (STR, gf/Tex) as a function of the cultivars and plant populations studied in 2017/2018. Montividiu, Goiás, Brazil. 2020.

\begin{tabular}{|c|c|c|c|}
\hline Cultivars & Fiber length (mm) & Short fiber index (\%) & Resistance $\left(\mathrm{gf} \mathrm{tex}^{-1}\right)$ \\
\hline TMG 44 B2RF & $29.86 \mathrm{bcd}$ & $10.92 \mathrm{bcd}$ & $28.69 \mathrm{bcd}$ \\
\hline TMG 47 B2RF & $28.87 \mathrm{e}$ & $11.82 \mathrm{ab}$ & $26.90 \mathrm{e}$ \\
\hline DP 1536 B2RF & $30.14 a b c$ & $9.17 \mathrm{e}$ & $30.64 \mathrm{a}$ \\
\hline DP 1746 B2RF & $30.27 \mathrm{ab}$ & $9.56 \mathrm{e}$ & $29.73 \mathrm{ab}$ \\
\hline IMA 5801 B2RF & 29.48 bcde & $9.29 \mathrm{e}$ & $28.26 \mathrm{cde}$ \\
\hline FM 954 GLT & $30.69 \mathrm{a}$ & $10.27 \mathrm{cde}$ & $30.37 \mathrm{a}$ \\
\hline FM 906 GLT & $29.41 \mathrm{cde}$ & $11.99 \mathrm{ab}$ & $27.60 \mathrm{de}$ \\
\hline FM 983 GLT & $29.12 \mathrm{de}$ & $12.67 \mathrm{a}$ & 29.08 abcd \\
\hline FM 985 GLTP & 29.50 bcde & $11.48^{a b}$ & $28.53 \mathrm{cde}$ \\
\hline BBX1506 & $28.74 \mathrm{e}$ & $11.30 \mathrm{abc}$ & $28.67 \mathrm{bcd}$ \\
\hline Population & $\begin{array}{c}\mathrm{Y}=30.07-004 \mathrm{X} \\
\mathrm{R}^{2}=0.81\end{array}$ & $\mathrm{Y}=10.84^{\mathrm{ns}}$ & $\mathrm{Y}=28.85^{\mathrm{ns}}$ \\
\hline
\end{tabular}

Note: Averages of treatments followed by the same letter in the column do not differ according to Tukey tests at 5\% significance level.

Table 6. Fiber length (LEN, mm) and fiber strength (STR, $\left.\mathrm{gf} \mathrm{tex}^{-1}\right)$ and short fiber index (SFI, \%) as a function of cultivars and plant populations studied in 2018/2019. Montividiu, Goiás, Brazil. 2020.

\begin{tabular}{lccc}
\hline Cultivars & Fiber length $(\mathrm{mm})$ & Short fiber index $(\%)$ & ${\text { Resistance }\left(\mathrm{gf} \mathrm{tex}^{-1}\right)}^{\mathrm{n}}$ \\
\hline IMA 6801 B2RF & $30.87 \mathrm{a}$ & $\mathrm{Y}=8.42^{\mathrm{ns}}$ & $28.87 \mathrm{~cd}$ \\
IMA 5801 B2RF & $29.67 \mathrm{bc}$ & $\mathrm{Y}=7.18^{\mathrm{ns}}$ & $29.38 \mathrm{abcd}$ \\
DP 1637 B2RF & $29.33 \mathrm{bc}$ & $\mathrm{Y}=8.61^{\mathrm{ns}}$ & $29.68 \mathrm{abc}$ \\
DP 1746 B2RF & $29.76 \mathrm{bc}$ & $\mathrm{Y}=8.21^{\mathrm{ns}}$ & $29.28 \mathrm{abcd}$ \\
TMG 44 B2RF & $29.34 \mathrm{bc}$ & $\mathrm{Y}=8.13^{\mathrm{ns}}$ & $29.91 \mathrm{bcd}$ \\
FM 906 GLT & $29.67 \mathrm{bc}$ & $\mathrm{Y}=9.42^{\mathrm{ns}}$ & $28.32 \mathrm{~cd}$ \\
FM 954 GLT & $31.20 \mathrm{a}$ & $\mathrm{Y}=7.60^{\mathrm{ns}}$ & $30.40 \mathrm{ab}$ \\
FM 944 GLT & $28.95 \mathrm{c}$ & $\mathrm{Y}=7.18^{\mathrm{ns}}$ & $30.45 \mathrm{a}$ \\
FM 983 GLT & $28.93 \mathrm{c}$ & $\mathrm{Y}=66.3-4.67 \mathrm{x}+3.40 \mathrm{x}^{2}-0.15 \mathrm{x}^{3}\left(\mathrm{R}^{2}=1.00\right)$ & $28.17^{\mathrm{d}}$ \\
FM 985 GLTP & $29.87 \mathrm{~b}$ & $\mathrm{Y}=8.01+0.27 \mathrm{x}^{2}\left(\mathrm{R}^{2}=0.66\right)$ & $28.91 \mathrm{bcd}^{\mathrm{n}}$ \\
\hline Population & $\mathrm{Y}=30.26-0.06 \mathrm{x}$ & & $\mathrm{Y}=29.23^{\mathrm{ns}}$ \\
\hline
\end{tabular}

Note: Averages of treatments followed by the same letter in the column do not differ according to Tukey tests at 5\% significance level.

\section{Conclusions}

The cultivars evaluated in this study did not show notably different responses as a function of the plant populations tested or the parameters evaluated. Increasing cotton plant population sizes, within the limits studied here, did not result in significant gains in fiber yield or in the technological characteristics of the fiber.

\section{Authors' Contribution}

Elio de Jesús Rodriguez de la Torre: participated in the planning, installation and conduct of the experiments. In addition to the collection, tabulation and processing of data as well as the interpretation of results and writing of the article. Fernando Mendes Lamas: participated in the organization, tabulation, statistical processing of experimental data; analysis and interpretation of results and writing of the article. Conception and design, and/or data acquisition and/or data analysis and interpretation.

\section{Bibliographic References}

Adams, C., Thapa, S., Kimura, E. 2019. Determination of a plant population density threshold for optimizing cotton int yield: A synthesis. Field Crops Research, 230, 11-16. DOI: org/10.1016/j.fcr.2018.10.005.

Alves, G.S., Tartaclia, F.L., Rosa, J.C., Ferreira, M., Carvalho, J.S., Alves, W.W.A. 2017. Crescimento, produtividade e qualidade de fibra de algodão colorido influenciados pela população de plantas. Revista Ceres, 64(1), 68-76. DOI: 10.1590/0034-737X201764010010.

Araújo, LF., Bertini, C.H.C.M, Bleicher, E., Vidal Neto, F.C. 2013. Características fenológicas, agronômicas e tecnológicas da fibra em diferentes cultivares de algodoeiro herbáceo. Agrária - Revista Brasileira de Ciências Agrárias, 8(3), 448453. DOI:10.5039/agraria.v8i3a2732.

Chiavegato, E.J., Bernardes, M.S., Carvalho, H.D.R. 2014. Estratégias para melhorar o aproveitamento da luminosidade na cultura do algodão. In: Echer, F.R. (Ed.). O algodoeiro e os estresses abióticos: temperatura, luz, água e nutrientes. IMAmt, Cuiabá, p. 43-61. 
Chiavegato, E.J., Silva, A.V., Gottardo, L.C.B. 2010. Densidade e arranjo de plantas em sistema adensado. In: Belot, J.L., Vilela, P.A. (Ed.). O sistema de cultivo do algodoeiro adensado em Mato Grosso: embasamentos e primeiros resultados. IMAmt, Cuiabá, p. 121-133.

Cia, E., Alleoni, L.R.F., Menezes, C.A., Fuzatto, M.G., Kondo, J.I., Carvalho, L.H., Chiavegato, E.J., Sabino, N.P. 1996. Densidade de plantio associada ao uso de regulador de crescimento na cultura do algodoeiro. Bragantia, 55(2), 309316. DOI: 0.1590/S0006-87051996000200016.

Cia, E., Furlani Junior, E., Sabino, N.P., Fuzatto, M.G., Ferraz, C.A.M., Carvalho, L.H., Bortoleto, N., Sabino, J.C., Campana, M.P. 2001. Eliminação do desbaste na cultura do algodoeiro. Pesquisa Agropecuária Brasileira, 36(10), 1239-1244. DOI: 10.1590/S0100-204X2001001000004.

Ferrari, S., Furlani Junior, E., Ferrari, J.V., Santos, D., Bencke, M.H. 2008. Desenvolvimento e produtividade do algodoeiro em função de espaçamentos e aplicação de regulador de crescimento. Acta Scientiarum Agronomy, 30(3), 365-371. DOI: 10.4025/actasciagron.v30i3.3546.

Ferreira, A.C.B., Borin, A.L.D.C., Brito, G.G., Silva Filho, J.L., Bogiani, J.C. 2015. Épocas de semeadura, cultivares e densidades de plantas para algodão adensado em segunda safra. Pesquisa Agropecuária Tropical, 45(4), 397-405. DOI: 10.1590/1983-40632015v4536869.

Guzmann, M., Vilain, L., Rondon, T., Sanches, J. 2019. Sowing Density Effects in Cotton Yields and Its Components. Agronomy, 9(7), 1-9. DOI: 0.3390/agronomy9070349.

Heitholt, J., Sassenrath-Cole, G. 2010. Inter-Plant Competition: Growth Responses to Plant Density and Row Spacing. In: Stewart J.M., Oosterhuis D.M., Heitholt J.J., Mauney J.R. (Ed.). Physiology of Cotton. Springer, Dordrecht, p. 179-186. DOI: 10.1007/978-90-481-3195-2_17.

IMEA. 2020. Algodão. http://www.imea.com.br/imeasite/relatorios-mercado (acessado 8 de julho de 2020).

Kaggwa-Asiimwe, R., Andrade-Sanchez, P., Wang, G. 2013. Plant architecture influences growth and yield response of upland cotton population density. Field Crops Research, 145, 52-59. DOI: 10.1016/j.fcr.2013.02.005.

Lamas, F.M., Ferreira, A.C.B. 2013. Arranjo espacial do algodoeiro como fator para otimizar a produtividade de fibra. Dourados, Embrapa Agropecuária Oeste, 23 p. (Embrapa Agropecuária Oeste. Documentos, 120).
Lima, J.J., Bélot, J-L. 2020. A fibra de algodão: qualidade e classificação, in: Belót, J-L., Vilela, P.M.C.A. (Ed.). Manual de boas práticas de manejo do algodoeiro em Mato Grosso, quarta edição, parte F. AMPA-IMAmt, Cuiabá, p. 382-409.

Meredith Junior, W.R., Boykin, D.L., Bourland, F.M., Caldwell, W.D., Campbell, B.T., Gannaway, J.R., Glass, K., Jones, A.P., May, L.M., Smith, C.W., Zhang, J. 2012. Genotype $\mathrm{X}$ environment interactions over seven years for yield, yield components, fiber quality, and gossypol traits in the regional high quality tests. Journal of Cotton Science, 16(3),160-169.

Reddy, K.N., Burke, I.C., Boykin, J.C., Williford, J.R. 2009. Narrow-row cotton production under irrigated and nonirrigated environment: plant population and lint yield. Journal of Cotton Science, 13(2), 48-55.

Ren, X., Zhang, L., Du, M., Evers, J.B., van der Werf, W., Tian, X., Li., Z. 2013. Managing mepiquat chloride and plant density for optimal yield and quality of cotton. Field Crops Research, 149, 1-10. DOI: 10.1016/j.fcr.2013.04.014.

Santos, H.G., Jacomine, P.K.T., Anjos, L.H.C., Oliveira, V.A., Lumbreras, J.F., Coelho, M.R., Almeida, J.A., Araujo Filho, J.C., Oliveira, J.B., Cunha, T.J.F. 2018. Sistema Brasileiro de Classificação de Solos, quinta edição. Brasília, DF, Embrapa.

Silva, P.T., Macedo, F.G., Camacho, M.A., Santos, C., Santi, A., Krause, W., Rambo, J.R. 2012. Spacing and plant density effect on reproductive development of herbaceous cotton. Scientia Plena, 8(5), 1-9.

Silvertooth, J.C., Edmisten, K.L., Mccarty, W.H. 1999. Production practices. In: Smith, W., Cothren, J.S. (Ed.). Cotton: Origin, History, Technology and Production. John Wiley \& Sons, New York, p. 451-488.

Sousa, D.M.G., Lobato, E. 2004. Correção da acidez do solo. In: Sousa, D.M.G., Lobato, E. (Ed.). Cerrado: correção do solo e adubação, segunda edição. Embrapa Cerrados, Planaltina, p. 147-168.

Stephenson, D.O., Barber, T., Bourland, F.M. 2011. Effect of twin-row planting pattern and plant density on cotton growth, yield, and fiber quality. Journal of Cotton Science, 5(3), 243250 .

Teixeira, P.C., Donagemma G.K., Fontana, A., Teiixeira, W.G. 2017. Manual de métodos de análise de solo, terceira edição. Brasília, DF, Embrapa, 573 p. 